\title{
Quantity Surveying Firms Survival of Fast Developing Economy
}

\author{
F.A.Rahim*, H. Abd-Rahman, C. Wang, N.D. Othman, N.Zainon \\ Faculty of Built Environment, University of Malaya, Kuala Lumpur. \\ azli@um.edu.my
}

\begin{abstract}
A recession or an economic downturn gave a tremendous impact on the Malaysian construction industry. The financial crisis seemed to be a wake-up call to all of the practitioners in the construction industry. Many of the QS consultant firms took strategic approaches to overcome the strike of the recession or economic downturn. The objective of this research is to determine the reaction of QS consultant firms towards the crisis that struck the nation Malaysia, a fast developing economy. Besides, this research reveals the recipe of survival of various QS consultant firms from the turmoil. Towards the end, the paper suggests suitable approaches to mitigate the impacts from an economic downturn for future survival of QS consultant firms. Data were collected through a questionnaire survey. The impact of an economic downturn or recession on QS consultant firms are seen in the decline of jobs, projects, and professional fees. Management theories were the main weapon used by the QS consultant firms to mitigate the negative impacts.
\end{abstract}

Keywords: quantity surveying firms, financial crisis, economic downturn, fast developing economy

\subsection{Introduction}

The construction industry plays a vital role in Malaysian economy. It contributes to the vast amount of economic growth. However like any industry, construction industry would be affected by any economic crisis whereby the quantity surveying (QS) firms is one of the main victim (Badawi, 2008). To ensure long-term survival of a firm, change management and innovation are crucial. During the recession and economic downturn, competition among the QS consultant was stiffed. Quantity surveying practice is indispensable in any construction development projects. The roles of quantity surveyors have also evolved along with this scenario (Fadhlin \& Ismail 2007). An economic downturn has a significant effect on the number of construction projects hence the quantity surveying practice will be much affected (Kaklauskas et al., 2011). Hanid et al. (2007) suggest that the QS consultant firms to take the challenge positively, because QS professions are fragile to the challenges faced. Economic downturn also known as recession can be defined as a period where the demand of raw material, products and services, including labour are decreased (Giang \& Low, 2011). The biggest impact of an economic downturn is reversal of capital flows. The reversal of capital flow can be described as the withdrawals of short term lines of credit, an exodus of portfolio capital, and offshore flight by domestic investors to the economies that has been attracting large amount of foreign capital (Wang, 2010).

Pheng \& Hua (2002) suggest that the management skills can be applied by construction firms to reduce the destructive effect of an economic downturn. According to Ariff \& Abu-Bakar (1999), during a recession, GDP 
experienced a significance contraction where the employment growth in the country become retarded and increases the unemployment rate. However, the survival of the local QS consultant firms could not yet be guaranteed. Grewal \& Tansuhaj (2001) indicate that an economic crisis did not influence all QS firms in a similar manner. Market orientation and strategic flexibility worked hand in hand to help firms to cushion the impact of an economic downturn (Chen et al., 2010). This contradicts with Shama (1993) whereby she indicated that the effect of economic downturn will varies accordingly to the type of sectors and size of the companies. In these circumstances, the manager must make a wise decision. In this study, through a questionnaire survey conducted in Malaysia, this paper is to determine the impact of a recession to QS consultant firms, to collect the applications of management theories by the QS consultant firms in mitigating the strike, and to suggest reasonable approaches to mitigate the negative impact of economic downturn in future.

\subsection{Economic Downturn and QS Firms}

CIDB (2011) stated that in Malaysia, the effects of the world economic downturn are felt during the fourth quarter of 2008 where the main sectors experienced decline in the growth and activities. See Table $2 \&$ Table 3.

The decline in the growth of the construction industry creates a domino effect to the consultant firms whereby they faced the financial imbalance and have a high debit rate (Pandelica et al., 2010). Central Bank of Malaysia (2011) indicates that the labour market condition will be more weakened with the unemployment rate approximately increase to $3.7 \%$ in 2009. In the second half of 2008, the labour market conditions weakened due to the business mainly in the manufacturing sector faced increasingly uncertain business environment. Table 4 shows that the labour market was expanded significantly up till the first half of 2008. It started to weaken in response to the cautious stance taken by the business sector following the steady rise in cost pressures and dwindling overseas demand as a result of the global economic and finance crisis. A rise in unemployment rate followed suit at 3.7\% (CIDB, 2011).

In Malaysia, a scale fee for consulting quantity surveyor is by the approved by the Ministry of Finance Malaysia. The scale of fees is mainly for the government physical projects. Fees for consulting quantity surveyor can be divided into two, fee payable for building and engineering works. With the very limited project in the market during an economic downturn, there is a vast competition between the QS consultant firm to compete for a job. At a time when, faced by an excess of supply over demand for surveying services, the construction industry saw the aggressive way in which many industry players now advertise and press for business to secure new clients. Fee competition is suddenly becoming a common phenomenon in the construction industries. Not only the surveying practices and industry players are competing for the work, the surveying profession is also said to be losing its share of the diminishing market to others. The large law, accountancy and consultancy firms are increasingly "infiltrating" the market for various forms of property management business, armed with competitive strategies to challenge the existing players. 
Drew et al. (2000) indicate that in several countries, competitive fee tendering is gaining popularity in the construction industry as a mechanism for allocating work to consultants such as architects, engineers and surveyors. Hoxley (1998) stated that in the UK, fee levels fell to unprecedented low levels due to the economic downturn. Royal Institution of Chartered Surveyors on the other hand stated that no member shall with the object of securing instructions or supplanting another member of the surveying profession, knowingly attempt to compete on the basis of fees and commissions. According to Boon (2001), the New Zealand Quantity Surveying firms were competing in an environment where they had survived the property market collapse with its shortage of work. With the tough competition in the current market, the firms were observed to react to the competitiveness of the market by lowering their cost structures and competing on the basis of lowest price. The current economic climate with the high competitive between the construction professionals operate with commissions of any size rarely being awarded without some form of fee tendering exercise. Based on a study done by Hoxley (1998), from 3 methods of appointment of construction professionals, half of the consultants assessed were appointed by competitive fee tendering as shown in Figure 1. Although a small proportion of professional firms have not survived the recent recession and the fall in fee levels, those that have survived, have done so by increasing their efficiency and accepting reduced profit levels.

Figure 1: Method of appointment of QS Consultants (Hoxley, 1998: 12)

\subsection{Impact of Economic Downturn to the Number of Projects}

Juhary et al. (2004) indicate that construction related firms are mainly relying on the number of projects to survive. Hence, competitions between QS firms are important to secure a job. According to Juhary et al. (2004), an economic downturn has a significance impact to Malaysian QS firms. He added that most of the firms are project-based and they basically obtain their jobs via competitive means. CIDB (2011) also added that in Malaysia the pattern growth of construction industry is based on the demands derived from Government sector and private sector. CIDB (2011) indicated that an average of 4889 projects worth RM44.11 billion per annum were awarded to local contractors during the period of 2001-2005 where the major impact of economic downturn is not felt yet. The Government sector offered a total of 7,888 projects while 15,254 projects were from the private sector as shown in Figure 2.

Figure 2: Quantity \& value of projects awarded during 2001-2005 (CIDB, 2011: 3)

In 2008, a significance impact to the number of project awarded is felt for 3 consecutive years starting from 2006. Hasan (2010) stated that in Ninth Malaysian Plan, the government announced additional budget and reassured that there is no cut back in government spending for construction activities. The demand of commercial and industrial properties will depend solely to the economic momentum whereas the demand of residential projects will depend on the public demand. On the other hand, the government projects are more dependants to the government development policies and spending (Hasan, 2010). 
Table 5: Number and value of projects awarded (Hasan, 2010: 3)

\subsection{Impact of the Economic Downturn to Entire Construction Industry}

Malaysia had attained robust economic growth since the 1980s. However, following the financial crisis and its protracted negative impact, economic growth has moderated. The more sedated global and local market conditions has resulted in the slowing down of the industry in the last five years with the contribution of the construction sector to GDP hovering around only $3 \%$ (CIDB, 2011). The construction industry consequently contracted significantly due to the plunge in private investment. With prudent initiatives put in place, the economy was lifted out of the doldrums, registering an impressive GDP growth. Figure 3 shows that the contribution of construction sector to Malaysian Economic growth. As shown below, the impact of economic downturn was felt by construction industry as early as 2004 and the fall the construction growth has affected the economic growth of Malaysia.

Figure 3: Construction sector growth \& Malaysian economic trend during 2001-2006 (CIDB, 2011: 1)

Figure 4 shows that the construction industry was felt badly and can be recognized based by looking at the first quarter of 2009 where the output value for construction sector fell drastically during that period of time. The drastic slump of GDP can also be seen by the first quarter of 2009.

Figure 4: Output value for construction sector of GDP year 1980-2009 (Construction Industry Development Board, 2011:1)

The construction industry is one of the most cyclic industries in Malaysia. It experiences higher highs and lower lows than any other industry. Thus, the fluctuation represents the most important constraint in the construction industry (Juhary et al., 2004). This shows that the quantity surveyor profession is very fragile due to the dependency to the growth of the construction industry.

\section{0 Possible Mitigation Approaches during Economic Downturn}

The survival of the companies relies on the action taken by marketing manager to alter marketing strategy during an economic crisis. Pheng \& Hua (2002) indicate that existing management theories can be applied by the consultants to mitigate the impact of economic downturn. The management theories include restructuring, downsizing, retrenchment, and marketing.

\subsection{Restructuring \& Downsizing}

A process of shifting the production from expensive site to the slightly cheaper is called restructuring (Cordove \& Dror, 1984). Organization restructuring is done by means of reducing their overheads and operating costs and 
increasing productivity by way of lay-offs, downsizing or reduction in wages (Cheung, 1999). However, Cascio (1993) term the downsizing as a planned reduction to company personnel. Based on Palliam \& Shalhoub (2002), restructuring is basically a method of restructuring process that involve retrenchments, downscaling, and down scoping. Bruke \& Cooper (2000) stated that laying off must be regarded as a continuous improving process that must be accompanied other initiatives of raising efficiency. According to Freeman \& Cameron (1993), downsizing can be understand in their four attributes: a) downsizing is an activity that organization pursue in a purposeful manner; b) downsizing normally involve personnel reduction; c) the purpose of organization undertake this option is to improve efficiency of the organization; and d) downsizing has its own impact directly or indirectly to the work process. The benefits of downsizing in an organization can be seen throughout the productivity of that company (Palliam \& Shalhoub, 2002). However, there are some negative significances by applying downsizing method in an organization whereby the morale of the employees affected will become low, management confusion, reduced the productivity of the employees, and lack of commitment in the organization later on.

Shaw \& Barrett-Power (1997) define downsizing as deliberating organizational decision to reduce the workforce that is intended to improve organizational performance. Palliam \& Shalhoub (2002) suggest that reducing staff is one of the methods of downsizing which include a combination reduction of physical, human and organizational systems. In her opinion, the impact of organizational downsizing to most organizations is not only unsuccessful but painful because the firm fails to consider the people factor. Palliam \& Shalhoub (2002) suggest that many organizations that have downsized have not achieved increase in productivity, instead they become smaller companies.

Figure 5: Types of downsizing (Appelbaum et al., 1999: 2)

\subsection{Retrenchment}

Schendel (1980) defined retrenchment as activities done by an organizational to reduce the cost and asset. Retrenchment is one of the methods that could be used by the consultant companies during an economic downturn or recession. McLaughlin (1990) stated that the main objective of retrenchment in organization is mainly to response to poor economic condition. This is because construction consulting firms have profits rise and fall with the general business cycle (Crespin-Mazet \& Portier, 2010). Latham (2009) in his framework on management's strategic response to the economic downturn highlighted that turnaround strategies may be adopted by a firm with three distinct strategic responses: a) cost reduction; b) asset reduction; and c) revenue-generation (See Figure 7)

Figure 6: Strategic responses of in turnaround strategies (Latham, 2009: 5)

Retrenchment consists of a combination of cost-cutting and asset-reducing activities; it is followed by the recovery process that seeks to regain the firm's pre-downturn level of performance (Duca et al., 2010). Retrenchment enhances a firm's recovery from declining performance. Michael \& Robbins (1998) defined retrenchment as a set of 
organizational activities undertaken to achieve cost and asset reductions and disinvestment. Advantage of retrenchment is organization is likely to achieve its main objective (Baguma, 2002). However Baguma (2002) argued that the effectiveness of retrenchment can be seen when the sequential steps of identifying the need for change, planning for the change, implementation, evaluation and feedback are followed. (See Figure 7).

Figure 7: Sequential steps for effectiveness of retrenchment (Baguma, 2002: 8)

\subsection{Marketing}

Marketing is the management function which organizes and directs all those business activities involved in assessing and converting customer purchasing power into effective demand for a specific product or service, and in moving a product or service to the final customer or user so as to achieve the profit target or other objectives set by the company (Chartered Institute of Marketing, 2011). Marketing is a social and managerial process by which individuals and groups obtain what they need and want through creating, and exchanging value with others (Kotler \& Armstrong, 2005). Professional services mainly deal with advices that delivered by skilled professionals. The scholars quoted 4 criteria to distinguish professional services from other services in the marketing mix: a) the service provided is conducted by qualified personnel, advisory in nature, and the focus is mainly on problem solving; b) the professionals must be well know in the market for their specialties with a specific name such as 'quantity surveyor' or architect; c) the service is in the form of assignment given by the buyers to the sellers; and d) the professionals must be independent of suppliers of other services or goods.

Jaafar et al. (2008) argue that the best method of successful marketing lies on its service quality rather than fee competition. She added that most of the professional practitioners in Malaysia for instance architect, engineers, and surveyors have neglected the importance of marketing where majority of them have a minimum understanding of marketing and its implementation. However, recession or an economic downturn occurs when the demand for a product is less compared to the normal period. On the other hand the core of marketing plan in an organization is to control and allocate resources. Marketing is one of the alternatives that consultant firms can utilize to increase volume instead of cutting profit margins.

On contrary, Jaafar et al. (2008) pointed out that the reason for the professional practitioners in Malaysia do not implement marketing mainly because most of the companies are small and medium sized whereby they have limited resources.

\subsection{Research Methods and Approach}

The main stage of this research is the preparation and collection of primary data. The primary data might change according to the current scenario of construction industry. A set of questions were designed to solicit the respondents' assessment in relation to the quantitative factors. This kind of data fulfils the criteria and objectives of 
this study because the data were linked closely to the real experience dealt by the QS firms during the recession. Naoum (1998) classified questionnaires into two types, which are the unrestricted type and the restricted type. In this study, the researcher employed both types. The questionnaire is prepared based on the issues discussed in the literature review. The questions were prepared in an objective manner, which covered the impact of economic downturn or recession on QS firms and approached how those companies came out with the strategic measures to overcome the economic downturn. The questionnaire form is divided into 3 parts, namely: Part A, B, and C. Part A consist of the background details of the respondents' firms. Part B consists of various impact of economic downturn suffered by the QS firms. The impacts were classified into the impact related to the number of projects undertaken, impact to the employment, and the QS professional fees. Part C mainly focuses on the mitigation strategies applied by the QS firms in overcoming the strike of the economic downturn. Part C covers also the effectiveness of those mitigation strategies.

First and foremost, the research team has listed down the necessary information of all the QS firms in Malaysia. The list and information of the firms was gathered from the Board of Quantity Surveyors Malaysia (BQSM). The particulars such as the company's name, brief history, state of operation, addresses, and contact number were jotted down for reference. Among those QS firms, 927 eligible respondents were selected. The questionnaires were sent through both postage together with the attachment of formal letter explaining the relevance and the purpose of the study. It is necessary to send a follow-up letters to those respondents who did not reply the said questionnaires. The follow-up letters were done through email. The duration between sending and collecting the survey forms was 3 weeks, after which 125 valid questionnaire forms were returned and collected.

There are 3 categories of QS firms in the survey. Out of 125 respondents, 59 of the QS consultant firms are registered as sole proprietor while 41 firms are based on partnership, and lastly 25 firms are body corporate.

\section{0 Analysis and Research Findings}

The obvious impact of a recession to QS consultant firms is the decline in number of projects. According to Figure $8,67 \%$ QS consultants firms responded that they faced a decreasing number of projects during the recent economic downturn while 33\% indicated that they did not face any decline in number of projects. In Figure 8, majority of the respondents (92\%) claimed that the impact of the global crisis was serious to the construction industry.

Figure 8: Impact of recession and an economic downturn to QS consultant firms in Malaysia

Clients are categorized into government sector and private sector. Figure 10 shows that during recent economic downturn, the clients of $64 \%$ QS consultants firms were mainly derived from the government sector while $36 \%$ were from the private sector. 
The major obstacles a Malaysian QS consultants firm faced during an economic downturn was basically project related problem, whereby $48 \%$ respondents indicated that although they secured quite an amount of projects, there were however some reduction in the scales of projects. In addition, $44 \%$ responded that they faced lack number of projects during an economic downturn.

Most of the companies still provided bonuses to their employees during an economic downturn although the potential recovery of economy was unpredictable. About $76 \%$ firms gave considerable amount of bonuses to their employees while $24 \%$ declined to pay bonuses to their employees. Due to the unpredictability of the global economic recovery, strategic measures have been taken by most respondents' firms. However, according to Figure 8, 92\% respondents did offer salary increase during the recession to increase the morale of their staff and to burst productivity of their employees. On the other hand, only $8 \%$ QS firms did not offer salary increase.

It was observed that during an economic downturn $48 \%$ QS firms would not hire any new employee. They would likely to wait for the recovery of the economic downturn for them to decide any change in their recruitment activities. There were 24\% QS firms maintained their yearly hiring rate while $20 \%$ of the firms were doing headcount and freeze recruitment. However, on the other hand, $8 \%$ QS firms were in the favour of hiring more people in their organization mainly to the increase in the number of projects.

In an economic downturn or recessions, the clients tended to show some negative feedbacks to those QS consultant firms. According to Figure 8, 76\% QS firms admitted that clients would delay their payment. 20\% respondents stated that the clients would cut down their professional fees while $4 \%$ experienced termination by the clients.

Based on the negative feedbacks by the clients as shown in Figure 8, 88\% admitted that an economic downturn was the main excuse for the delay in payment, cutting down professional fees, and termination of QS consultant firms' services. On the other hand, $12 \%$ respondents were on their opinion that the delay in payment to the QS consultant firms was due to some reasons other than the economic downturn.

There were 36\% QS firms implemented the necessary cost-cutting measures such as reducing overtime, minimize daily operation costs, and practicing extended shutdowns in festive periods. There were $48 \%$ used marketing tools to enhance the productivity of the company. $8 \%$ of the respondents stated that they implemented restructuring in their firm in order for them to survive the impact of the economic downturn while $8 \%$ the respondents indicate that downsizing is their favourite choice to mitigate economic downturn. There were $84 \%$ QS firms considered enhancing the competencies and competitiveness of their employees through skills enhancement or re-training programmes. Only 16\% firms had no such plans in the crisis. This was in line with the Government's efforts to encourage employers to provide more training opportunities and to re-train their workers in enhancing their competencies and competitiveness under the economic stimulus packages that were allocated a total sum RM650 million for human resources training purpose. The types of training that respondents stressed on included the project 
supervisory and management, self development, and management skills such as training on enhancing competency, social skills and motivation.

\section{0 Discussions on Findings}

Malaysia has not been spared along with the rapid weakening in the global economy. Economic activity in Malaysia has slowed significantly since the second half of 2008 because of the impact of high trade and investment with the United States, European Union, and Japan. However, with Malaysia's strong economic fundamentals, the economy was expected to weather the current global economic challenges and maintain its performance. While it was foreseeable that the Malaysian economy would undergo some soft patches in the short term, it should continue to remain stable, healthy and far from the financial and economic crisis that will continue to linger in the developed economies. However, because of the high economic interdependency between Malaysia and the developed economies, there would be limitations to which Malaysia and also other emerging economies can ride out from the global economic slowdown, if the present recession in the west deepen and prolong. The effect of an economic downturn to QS consultant firms in Malaysia were observed in 3 perspectives, first, the employment and recruitment activities; second, the number of projects undertaken by QS consultant firms; and finally the professional fees of QS consultant firms. During an economic downturn, many directors of QS consultant in Malaysia took a quite number of strategic measures. Majority of them did not hire new employees. This survey reflects the decline in employment during an economic downturn. The number of projects undertaken by QS consultant firms was basically a reflection of a string relationship among the construction professionals. The effects were thoroughly as the impact of economic downturn to the construction industry produced a simultaneously impact called "domino effects". Malaysian QS consultant firms experienced a decline in number of projects due to the slump in construction activities during the downturn. Moreover, the impact was also seen in the cutting of professional fees by clients. Because of the stiff competition and very limited projects in the market during the economic downturn, there is a vast competition between the QS consultant firm to compete for a job. Most QS consultant firms revealed that their professional fee are in jeopardize.

The construction industry is unstable where the demand is highly sensitive and very much dependable on the development in other sectors of the economy. QS Practices was said to be threatened by the current and future scenario in terms of demand and need of the clients. Therefore in order to survive in the industry, QS firms need to take very careful and strategic measures to resist the impact of economic downturn. From the results of this survey, it was noted that all QS firms have applied at least one management approach to mitigate the economic downturn. Majority of them have taken cost cutting measures during the downturn. Moreover, majority of the QS consultant firms have their own marketing strategy whereby they develop the marketing strategy through networking. However, most QS firms in Malaysia still provided bonuses to their employees during the economic downturn although the potential recovery of economy was unpredictable. In addition, more than $90 \%$ QS firms did offer salary increase during the economic downturn to increase the morale of their staff and to burst productivity of their 
employees, which was probably the secret of survival of Malaysian QS firms in the crisis. It suggested that QS firms to make a wise decision before any mitigation approaches were applied in future crisis. The morale of employees was negatively affected towards downsizing. Retrenchment incurred a lot of cost as well. Those methods should be the last resort for a manager to apply in future.

\section{0 Conclusion and Recommendations}

This research reveals the recipe of the survival of Malaysian QS firms from an economic crisis or recession. Towards the end, the researcher suggests suitable approaches for QS firms to mitigate the economic downturn in future. Findings indicate that the effects of economic downturn to QS firms were seen in the decline of jobs, projects, and also professional fees. Management theories were the main weapon used by the management of the QS consultant firm to mitigate the economic downturn. The researcher identified several issues which can be further explored. Future study can be conducted to determine the impact of economic downturn to various professionals in the industry including contracting firms and architectural firms and to evaluate the government initiatives to help those affected firms to survive.

\section{0 References}

Appelbaum, H. A., Lavigne-Schmidt, S., Peytchev, M., \& Shapiro, B. 1999. 'Downsizing:measuring the costs of failure', Journal of Management Development,18(5): 436-463.

Ariff, M. and Abu-Bakar, S.Y. 1999. 'The Malaysian Financial Crisis: Economic Impact And Recovery Prospects', The Developing Economies, 37(4): 417-438.

Badawi, A.A. 2008. Introducing the Motion to Table the Mid-Term Review Of the Ninth Malaysia Plan. Mid-term Review Ninth Malaysia Plan 2006-2010. Putra Jaya: The Office of Malaysia Prime Minister's Office.

Baguma, P. and Matagi, L. 2002. Effects of the Retrenchment Exercise on Organizational Performance and Quality of Work Life Among Ugandan Public Officers. Published thesis, NURRU, Uganda.

Boon, J. 2001. New Zealand Quantity Surveying Practice - Continuing to Adapt in a Changing Environment. In COBRA 2001 conference Papers. Glasgow: RICS Glasgow Caledonian University.

Bruke, R.J.and Cooper, C.L 2000. Organization in crisis: downsizing, restructuring, and privatization. London: Wiley-Blackwell.

Central Bank of Malaysia. 2011. Bank Negara Malaysia Annual Report 2008. Retrieved January 10, 2011, from http://www.bnm.gov.my/view.php?dbIndex=0\&website_id=1\&id=694.

Chartered Institute of Marketing. 2011. Definition of Marketing. [online] URL: http://www.cim.co.uk/resources/understandingmarket/definitionmkting.aspx

Chen, J.H., Yang, L.R., Su, M.C., and Lin, J.Z. 2010. 'A rule extraction based approach in predicting derivative use for financial risk hedging by construction companies', Expert Systems with Applications, 37(9): 6510-6514. 
Cheung, M.K.C. 1999. Human Resources Management Policy, Strategies and Actions to Minimize the Effect of Economic Retrenchment: The Experience of the Hong Kong Special Administrative Region (HKSAR), China. Seminar on HR Management Policy, Strategies and Actions to Minimize the Effects of Economic Retrenchment in the Region, 20th APEC HRD Working Group Meeting, HKSAR: Asia-Pacific Economic Cooperation.

Construction Industry Development Board. 2011. Macro Economic Review And Outlook 2007. [online] URL: www.cidb.gov.my/v6/files/country_report.pdf

Crespin-Mazet, F., and Portier, P. 2010. 'The reluctance of construction purchasers towards project partnering', Journal of Purchasing and Supply Management, 16(4): 230-238.

Drew, D.S., Ho, L.C.Y., and Skitmore, M. 2001. 'Analyzing a Consultant's Competitiveness in Two Envelope Fee Tendering', Construction Management and Economics, 19(5): 503-510.

Duca, J.V., Muellbauer, J., and Murphy, A. 2010. 'Housing markets and the financial crisis of 2007-2009: Lessons for the future', Journal of Financial Stability, 6(4): 203-217.

Fadhlin, A. and Ismail, H. 2007. Profile of the Quantity Surveying Practice in Malaysia. PhD Thesis, Faculty of Built Environment, Universiti Teknologi Malaysia.

Freeman, S. J. and Cameron, K. S. 1993. 'Organizational Downsizing: a Convergence and Reorientation Framework', Organization Science, 4(1): 10-29.

Giang, D.T.H. and Low, S.P. 2011. 'Role of construction in economic development: Review of key concepts in the past 40 years', Habitat International, 35(1): 118-125.

Grewal, R. and Tansuhaj, P. 2001. 'Building Organizational Capabilities for Managing Economic Crisis: The Role of Market Orientation and Strategic Flexibility', Journal of Marketing, 65: 67-80.

Gummesson, E. 1978. 'Towards a theory of professional service marketing', Industrial Marketing Management, 7(2): 89-95.

Hanid, M., Zakaria, N., Karim, S.B.A., Stabal, L.A.W., and Lee, T.Y. 2007. 'Beyond the Tradition: Venturing Quantity Surveying Services in the Non-Construction Sectors', Paper presented at Quantity Surveying International Conference, Malaysia.

Hoxley, M. 1998. Value for Money? The Impact of Competitive Fee Tendering on Construction Professional Service Quality. The Royal Institution of Chartered Surveyors, London.

Jaafar, M., Aziz, A.R.A., and Wai, A.L.S. 2008. 'Marketing Practices of Professional Engineering Consulting Firms: Implement or Not to Implement', Journal of Civil Engineering And Management, 14(3): 199-206.

Juhary A., Chew, T.G., and Tang, T.C. 2004. 'Knowledge Management in Agile Organizations', Sunway College Journal, 1: 13-20.

Kaklauskas, A., Kelpsiene, L., Zavadskas, E.K., Bardauskiene, D., Kaklauskas, G., Urbonas, M., Sorakas, V. 2011. 'Crisis management in construction and real estate: Conceptual modeling at the micro-, meso- and macrolevels', Land Use Policy, 28(1): 280-293.

Kotler, P. and Armstrong, G. 2006. Principles of Marketing, 11th edn, Pearson-Prentice Hall Englewood Cliffs. 
Latham, S. 2009. 'Contrasting Strategic Response to Economic Recession in Start-Up versus Established Software Firms', Journal of Small Business Management, 42(2): 180-201.

McLaughlin, M. 1990. 'How to Survive a Recession', New England Business, 7: 35-37.

Michael, S.C. and Robbins, D.K. 1998. 'Retrenchment among Small Manufacturing Firms during Recession', Journal of Small Business Management, 36(3): 35-46.

Naoum, S.G. 1998. Dissertation Research and Writing for Construction Students. London: Butterworth Heinemann.

Palliam, R. and Shalhoub, Z.K. 2002. 'Rationalizing Corporate Downsizing with Long-Term Profitability: An Empirical Focus', Journal of Management Decision, 40(5): 436-447.

Pandelica, I., Pandelica, A., and Dabu, B. 2010. 'The Response of Organizations in Crisis Conditions', The Journal of American Academy of Business, Cambridge, 15(2): 1-11.

Pheng, L.S. and Hua, L.N. 2002. 'The Strategic Responses of Construction Firms to the Asian Financial Crisis in 1997-1998', International Journal of Construction Marketing, 1(2): 1-13.

RIBA. 1993. Strategic Study of the Profession. Phase I: Strategic Overview. London: RIBA.

Shama A. 1993. 'Marketing Strategies during Recession: A Comparison of Small and Large Firms', Journal of Small Business Management, 31(3): 62-73.

Shaw, J.B. and Barrett-Power, E. 1997. 'A conceptual framework for assessing organizations, work group and individual effectiveness during and after downsizing', Human Relations, 50(2): 19-27.

Wang, J.C. 2010. 'The strategies adopted by Taiwan in response to the global financial crisis, and Taiwan's role in Asia-Pacific economic integration', Japan and the World Economy, 22(4): 254-263.

\section{Figure Captions:}

Figure 1: Method of appointment of QS Consultants (Hoxley, 1998: 12)

Figure 2: Quantity \& value of projects awarded during 2001-2005 (CIDB, 2011: 3)

Figure 3: Construction sector growth \& Malaysian economic trend during 2001-2006 (CIDB, 2011: 1)

Figure 4: Output value for construction sector of GDP year 1980-2009 (Construction Industry Development Board, 2011: 1)

Figure 5: Types of downsizing (Appelbaum et al., 1999: 2)

Figure 6: Strategic responses of in turnaround strategies (Latham, 2009: 5)

Figure 7: Sequential steps for effectiveness of retrenchment (Baguma, 2002: 8)

Figure 8: Impact of an economic downturn to QS consultant firms in Malaysia 


\section{TABLES}

Table 1: Growth of GDP Malaysia from 2004 to 2007 at constant price 2000 (CIDB, 2011: 2)

\begin{tabular}{|l|c|c|c|c|}
\hline Sector & $\mathbf{2 0 0 4}$ & $\mathbf{2 0 0 5}$ & $\mathbf{2 0 0 6}$ & $\mathbf{2 0 0 7}$ \\
\hline Agriculture, forestry, fishery & & & & \\
\hline Mining and quarrying & 4.7 & 2.6 & 5.2 & 1.4 \\
\hline Manufacturing & 4.1 & -0.4 & -1.0 & 2.0 \\
\hline Services & 9.6 & 5.2 & 6.7 & 3.1 \\
\hline Construction & 6.4 & 7.2 & 7.4 & 9.6 \\
\hline GDP & -0.9 & -1.5 & -0.3 & 4.7 \\
\hline
\end{tabular}

Table 2: Malaysia GDP and Annual Growth from 2008 to 2010 (Department of Statistics Malaysia)

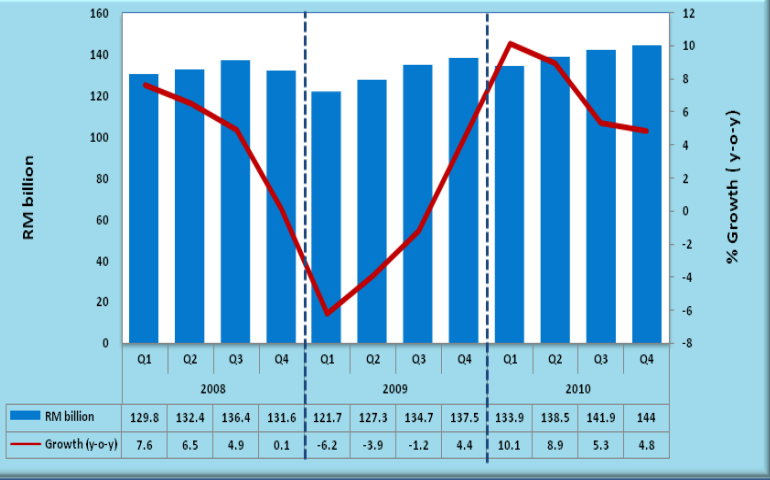

Table 3: Malaysia GDP and Annual Growth by Sector from 2008 to 2010 (Department of Statistics Malaysia)

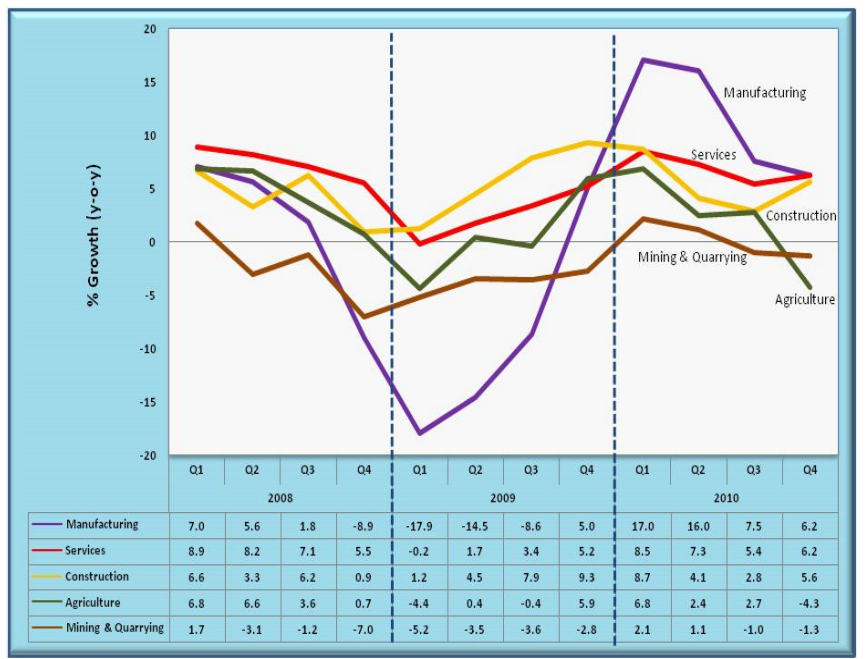


Table 4: Labour market indicator (CIDB, 2011: 5)

\begin{tabular}{|l|c|c|c|c|c|c|c|}
\hline & $\mathbf{2 0 0 4}$ & $\mathbf{2 0 0 5}$ & $\mathbf{2 0 0 6}$ & $\mathbf{2 0 0 7}$ & $\mathbf{2 0 0 8}$ & $\mathbf{2 0 0 9}$ & $\mathbf{2 0 1 0}$ \\
\hline Population (people) & $\begin{array}{c}26.0 \\
\text { million }\end{array}$ & $\begin{array}{c}26.1 \\
\text { million }\end{array}$ & $\begin{array}{c}26.6 \\
\text { million }\end{array}$ & $\begin{array}{c}27.2 \\
\text { million }\end{array}$ & $\begin{array}{c}27.7 \\
\text { million }\end{array}$ & $\begin{array}{c}28.3 \\
\text { million }\end{array}$ & $\begin{array}{c}29.1 \\
\text { million }\end{array}$ \\
\hline Population growth rate & $2.8 \%$ & $0.4 \%$ & $1.9 \%$ & $2.3 \%$ & $1.8 \%$ & $2.3 \%$ & $2.5 \%$ \\
\hline Labour force (people) & $\begin{array}{c}10.5 \\
\text { million }\end{array}$ & $\begin{array}{c}10.9 \\
\text { million }\end{array}$ & $\begin{array}{c}11.2 \\
\text { million }\end{array}$ & $\begin{array}{c}11.4 \\
\text { million }\end{array}$ & $\begin{array}{c}11.5 \\
\text { million }\end{array}$ & $\begin{array}{c}11.6 \\
\text { million }\end{array}$ & $\begin{array}{c}11.8 \\
\text { million }\end{array}$ \\
\hline $\begin{array}{l}\text { Labour force growth } \\
\text { rate }\end{array}$ & $4.1 \%$ & $4.1 \%$ & $2.4 \%$ & $2.1 \%$ & $1.1 \%$ & $0.8 \%$ & $1.5 \%$ \\
\hline $\begin{array}{l}\text { Unemployment rate } \\
\text { (\% from labour force) }\end{array}$ & $3.5 \%$ & $3.5 \%$ & $3.3 \%$ & $3.2 \%$ & $3.3 \%$ & 3.7 & $3.5 \%$ \\
\hline
\end{tabular}

Table 5: Number and value of projects awarded (Hasan, 2010: 3)

\begin{tabular}{|l|l|l|l|l|l|l|}
\hline \multirow{2}{*}{ Year } & Total contract awarded & \multicolumn{2}{l|}{ Government contract } & Private contract \\
\cline { 2 - 7 } & Number & $\begin{array}{l}\text { Value } \\
\text { (RM Billion) }\end{array}$ & Number & $\begin{array}{l}\text { Value } \\
\text { (RM Billion) }\end{array}$ & Number & $\begin{array}{l}\text { Value } \\
\text { (RM Billion) }\end{array}$ \\
\hline 2006 & 5,860 & 60.93 & $1,652(28.1 \%)$ & $22.45(36.9 \%)$ & $4,208(71.9 \%)$ & $38.48(63.1 \%)$ \\
\hline 2007 & 7,070 & 90.46 & $2,880(40.7 \%)$ & $47.48(52.5 \%)$ & $4,190(59.3 \%)$ & $42.98(47.5 \%)$ \\
\hline 2008 & 6,443 & 85.25 & $2,066(32.1 \%)$ & $27.61(32.4 \%)$ & $4,377(67.9 \%)$ & $57.64(67.6 \%)$ \\
\hline 2009 & 6,531 & 68.6 & $3,134(47.9 \%)$ & $32.93(48 \%)$ & $3,397(52.1 \%)$ & $35.67(52 \%)$ \\
\hline
\end{tabular}

\section{FIGURES}

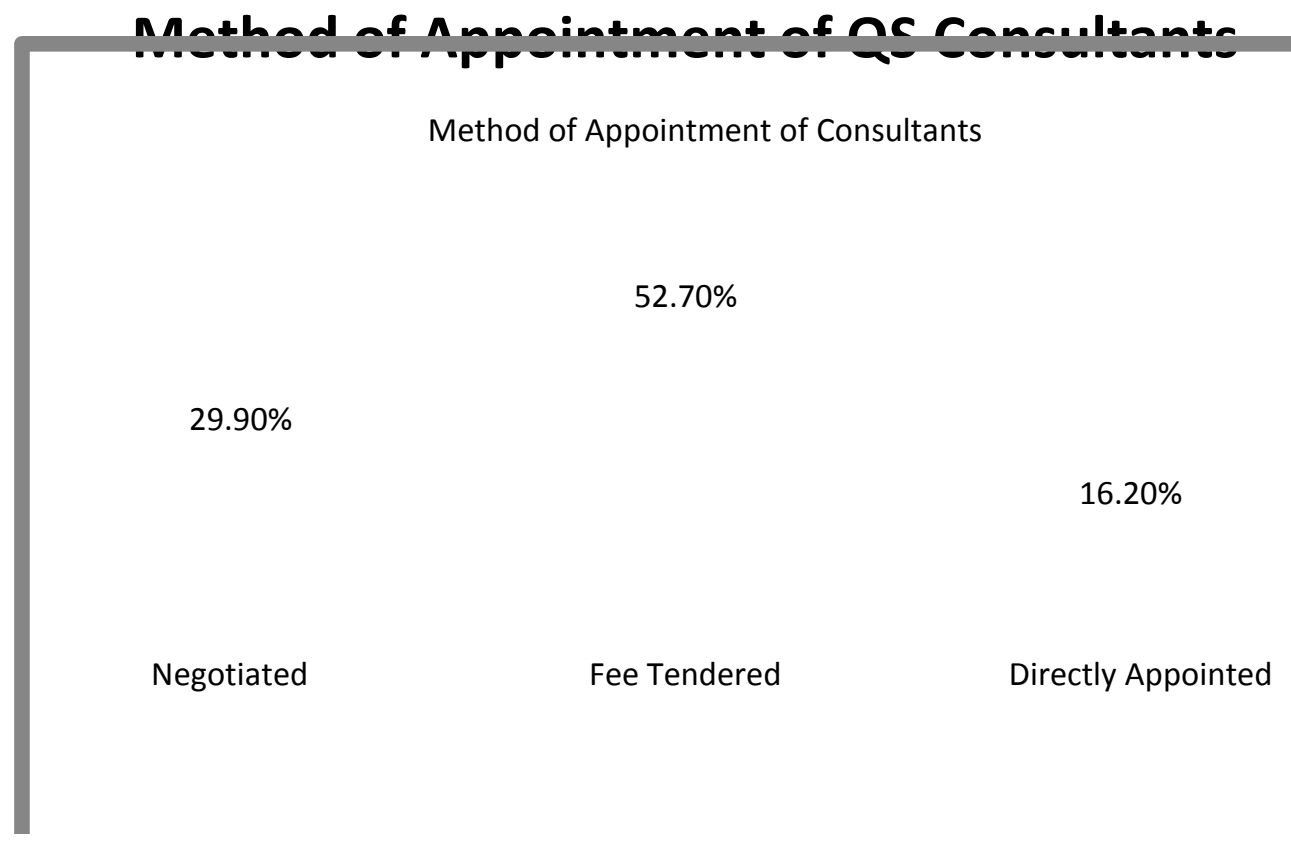

Figure 1: Method of appointment of QS Consultants (Hoxley, 1998: 12) 

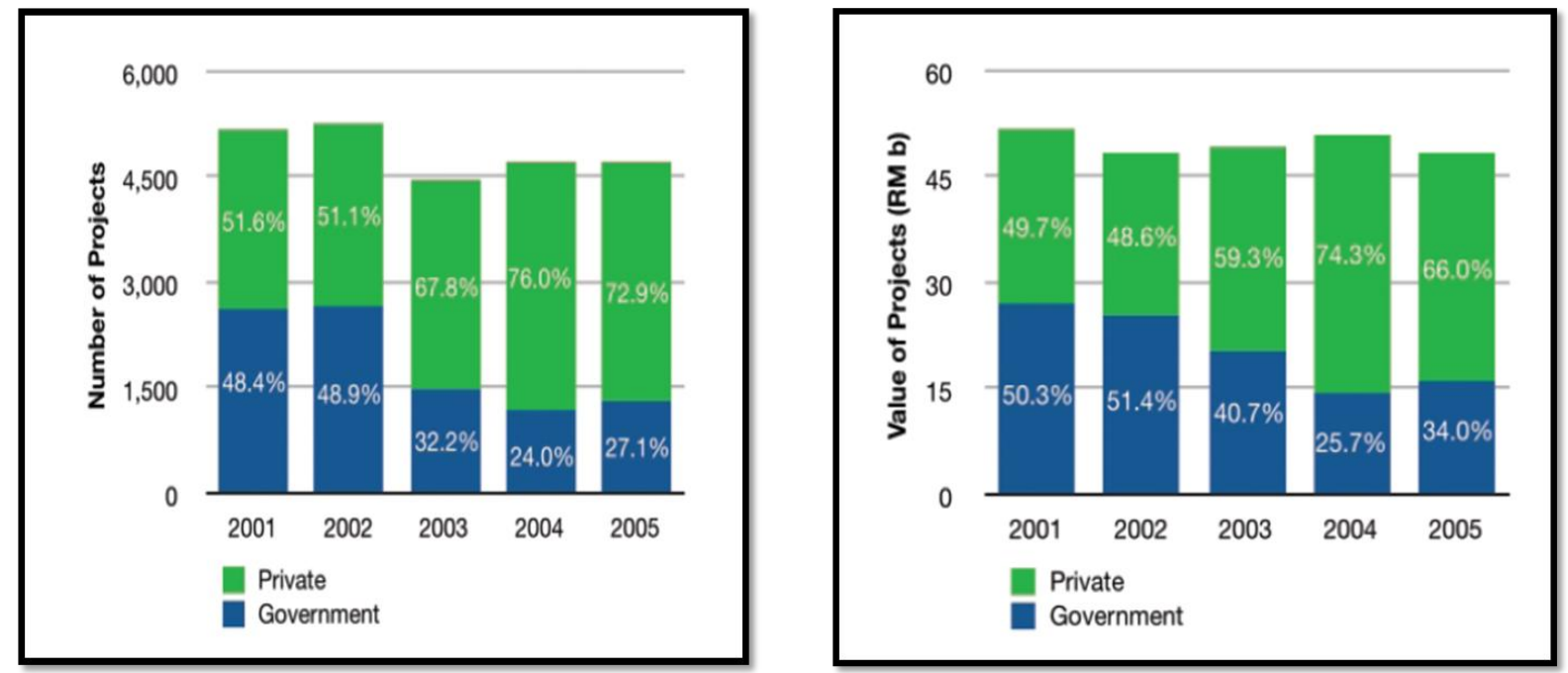

Figure 2: Quantity \& Value of projects awarded during 2001-2005 (CIDB, 2011: 3)

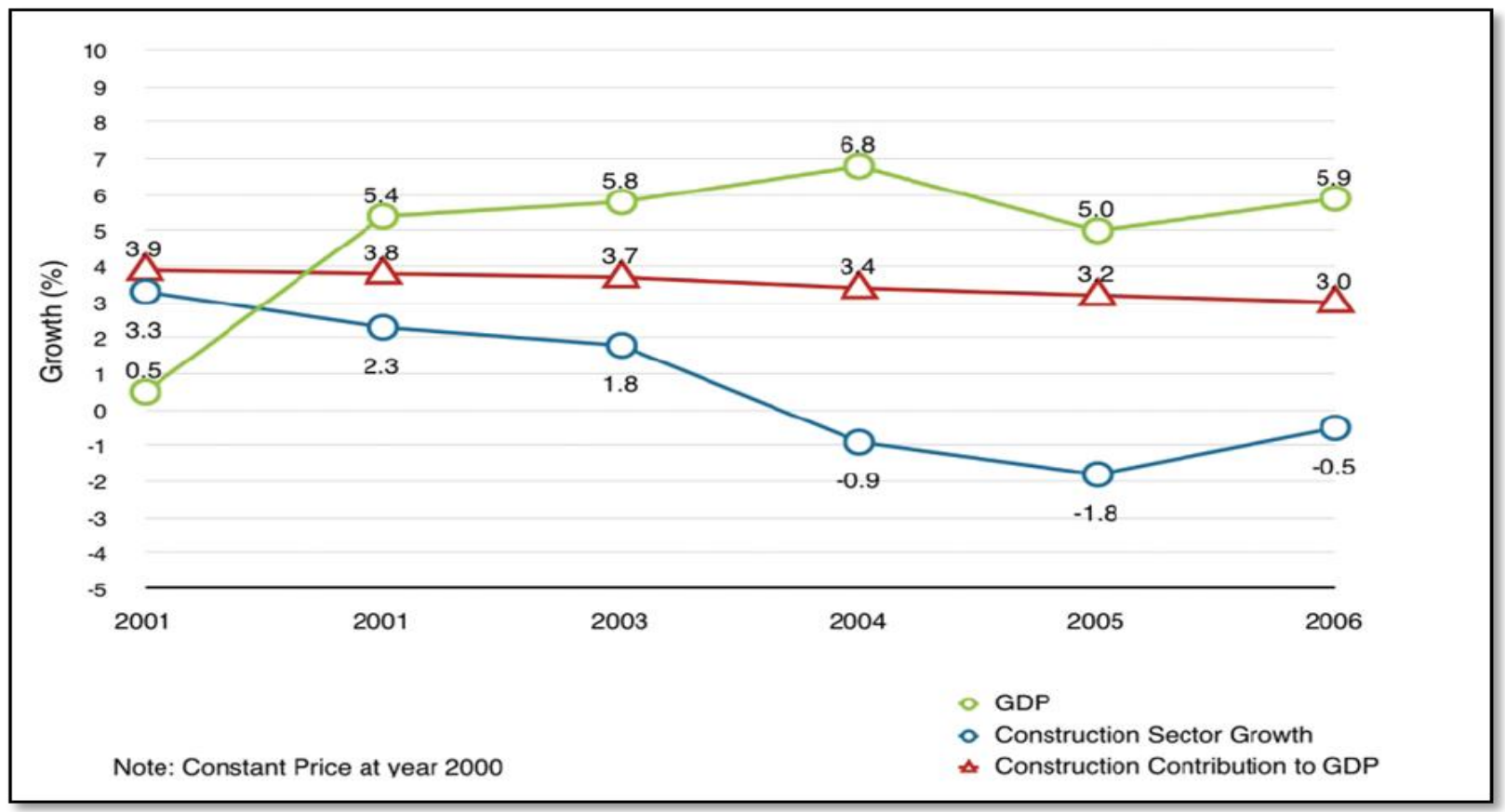

Figure 3: Construction sector growth \& Malaysian economic trend during 2001-2006 (CIDB, 2011: 1) 


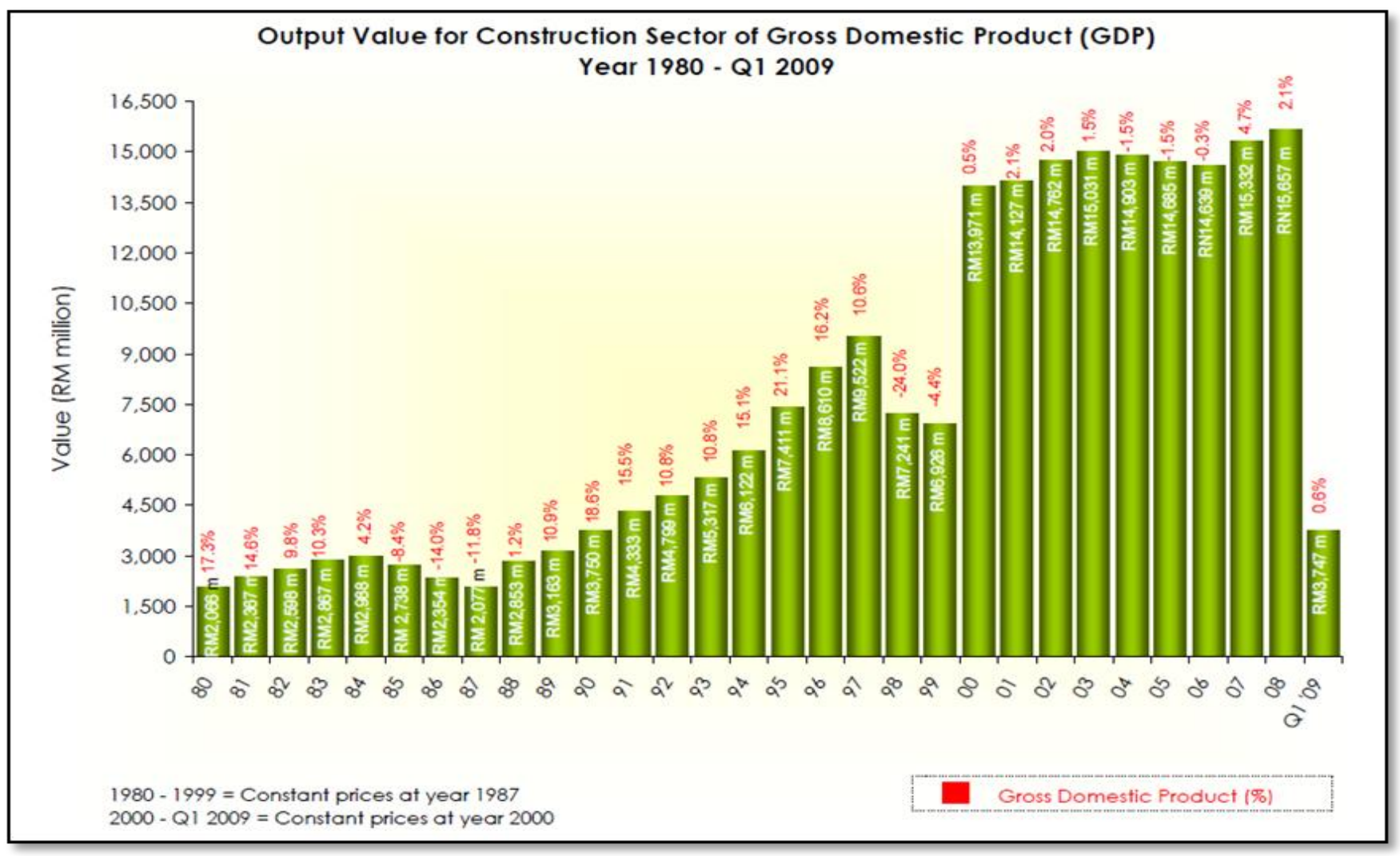

Figure 4: Output value for construction sector of GDP year 1980-2009 (Construction Industry Development Board, 2011: 1)

\begin{tabular}{|c|c|c|c|c|}
\hline $\begin{array}{c}\text { Across the board } \\
\text { cutbacks }\end{array}$ & $\begin{array}{c}\text { - Each cgeompany department is expected to reduce } \\
\text { personnel or budget by a fixed percent }\end{array}$ \\
\hline $\begin{array}{c}\text { Early retirement \& } \\
\text { voluntary turnover }\end{array}$ & $\begin{array}{c}\text { - To entice employees to leave the company of their } \\
\text { own free will by the removal of penalties from early } \\
\text { application for retirement pension plan benefits }\end{array}$ \\
\hline $\begin{array}{c}\text { Delayering the } \\
\text { Organization }\end{array}$ & $\begin{array}{c}\text { - one or more horizontal slices of the organization are } \\
\text { eliminated }\end{array}$ \\
\hline Contracting out & \begin{tabular}{c} 
- Outsourcing of non-core activities of the company \\
\hline Eliminating product
\end{tabular} & $\begin{array}{c}\text { - Where company decides to divest itself of a set of } \\
\text { businesses or programs }\end{array}$ \\
\hline line or divisions
\end{tabular}

Figure 5 : Types of downsizing (Appelbaum et al., 1999: 2) 


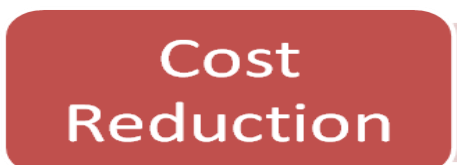

- Employ by firm that are closed to break-even point

- Firm require short-term fix to demonstrate profitability

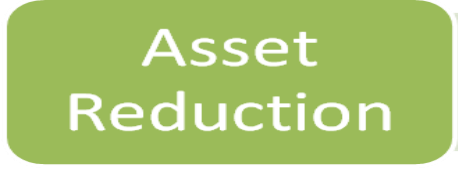

- Adopted by firm to response to environmental uncertainty

- Last resort strategy

- Firms are furthest away from break-even point

\section{Revenue- generation}

- Adopted by firms to avoid short-term cash flow - Mainly focus on area that offer highest probability to operate profits

Figure 6: Strategic responses of in turnaround strategies (Latham, 2009: 5)

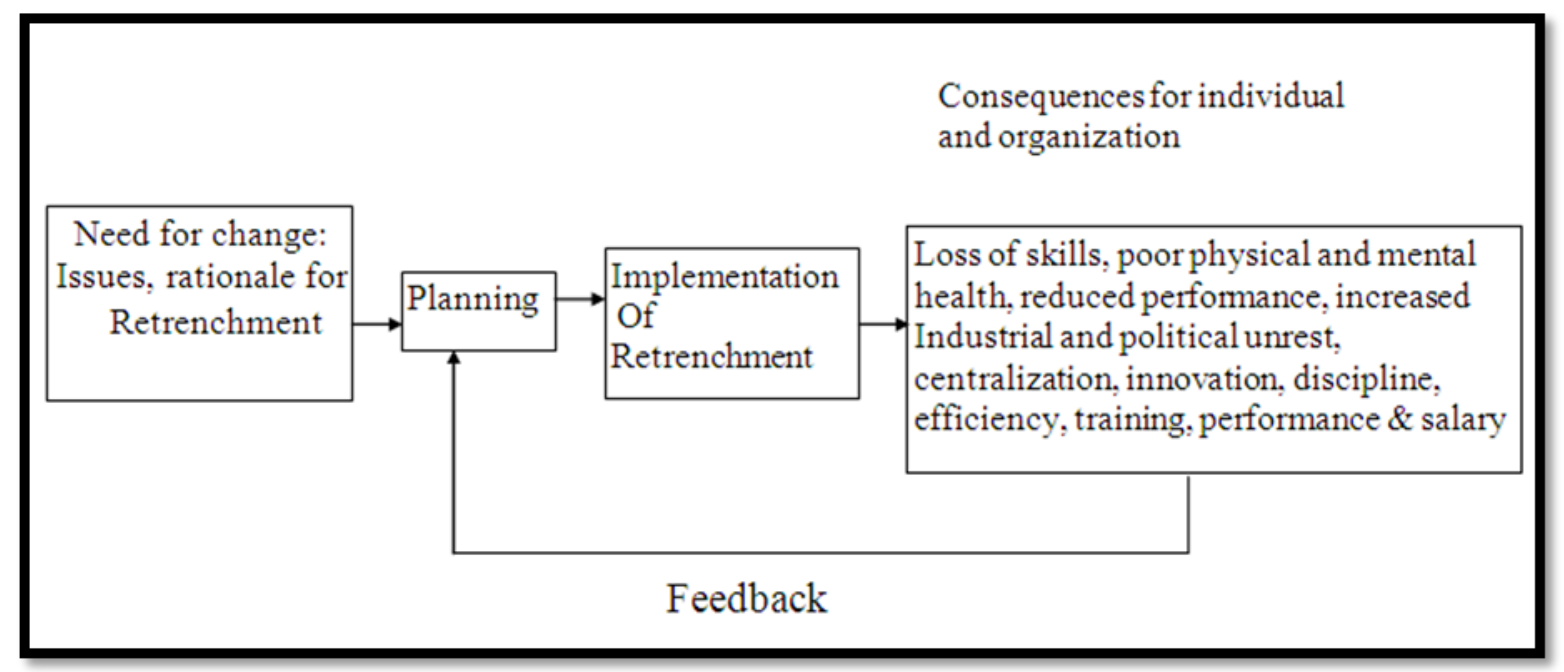

Figure 7: Sequential steps for effectiveness of retrenchment (Baguma, 2002: 8) 


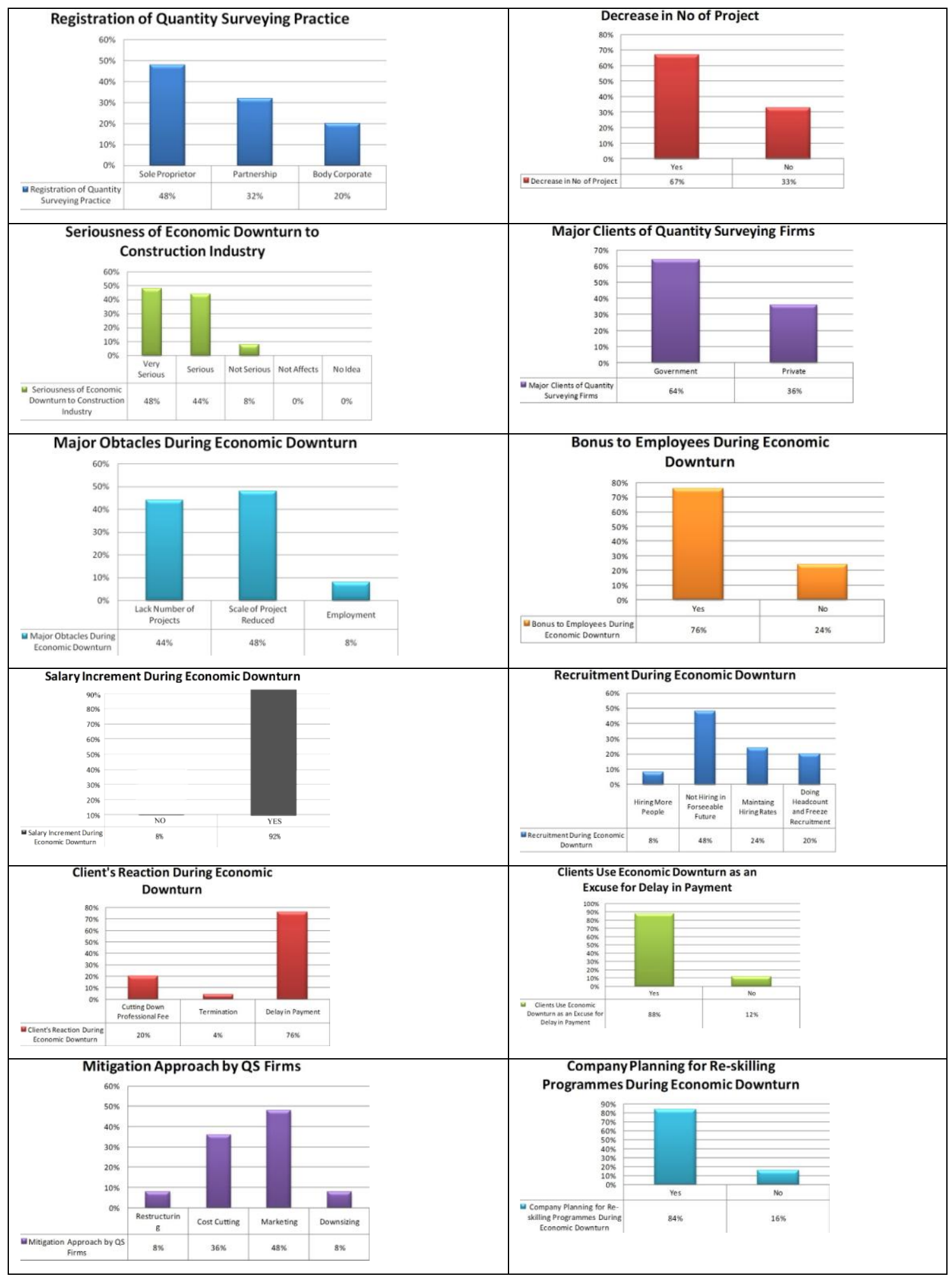

Figure 8: Impact of economic downturn to QS consultant firms in Malaysia 